\title{
More health staff are needed to contain Ebola outbreak, warns WHO
}

\author{
Anne Gulland \\ London
}

A lack of health workers and materials is hampering efforts to contain the Ebola outbreak in west Africa, World Health Organization officials have warned.

At a press conference to provide more information on WHO's "roadmap" to guide and coordinate the international response to the outbreak, ${ }^{1}$ Keiji Fukuda, WHO's assistant director general for health security, said that the "single most important" thing holding back relief efforts was that "we don't have enough people on the ground"-including health workers, laboratory technicians, drivers, and mortuary workers. It takes 200 to 250 people to care for 80 patients with Ebola, said Fukuda, who added that several thousand more health workers were needed to contain the epidemic.

The latest figures on the outbreak, dated 28 August, showed that Guinea, Sierra Leone, Liberia, and Nigeria had had 3069 confirmed cases, including 1552 deaths. The disease has only recently spread to Nigeria, where the outbreak is still small, and a single case of the disease has been reported in Senegal.

Epidemiological evidence and virus sequencing showed that an outbreak in the Democratic Republic of Congo - which has had 24 cases of haemorrhagic fever, including 13 deaths, in the past two months-was not linked to the west African outbreak. However, WHO has predicted at least 20000 cases of Ebola before the outbreak is contained, which it aims to do within six to nine months.

Margaret Chan, WHO director general, responded to criticism that WHO and other United Nations agencies had failed to implement a large scale response similar to that seen during last year's typhoon in the Philippines and the 2010 Haiti earthquake. Chan said that the Ebola outbreak was different from other humanitarian disasters in terms of the "fear and anxiety" it generated: foreign medical teams had been unwilling to help, making it difficult to mount an adequate response. Airports and ports in the affected countries have also been closed, as airlines are unwilling to put their staff at risk. However, WHO said it hoped that discussions with international aviation organisations would help flights to resume within the next two weeks.

Joanne Liu, international president of Médecins Sans Frontières - one of the few organisations providing a frontline medical response in west Africa-earlier this week pleaded with
UN world leaders to "immediately deploy civilian and military assets with expertise in biohazard containment."

She said, "I call upon you to dispatch your disaster response teams, backed by the full weight of your logistical capabilities," adding that the time for planning and meetings was over. With the implementation of its roadmap, WHO said that it aimed to reverse the trend in new cases and infected areas within three months, stop transmission in capital cities and major ports, and stop all residual transmission within six to nine months.

David Nabarro, senior UN system coordinator for Ebola virus disease, said he believed that the response would cost at least $\$ 600 \mathrm{~m}(£ 365 \mathrm{~m} ; € 456 \mathrm{~m})$. Part of that response included ensuring that staff caring for patients were protected, received appropriate medical treatment if they got ill, and were properly paid. He added that controlling the outbreak was "doable" but that the international response needed to be "three or four" times bigger. In another development, Will Pooley, the British nurse flown back to the United Kingdom after contracting Ebola while caring for patients in Sierra Leone, has been declared free of the disease. Pooley, who was treated in a high level isolation unit at the Royal Free Hospital in London, was given the experimental drug ZMapp, although doctors did not know if this contributed to his recovery.

At a press conference Pooley thanked medical staff, as well as the UK government, which paid for his evacuation, but he said, "The standard of care I received was a world apart from what people are getting in west Africa, despite the best efforts of the healthcare workers out there."

thebmj.com News: US signs contract with ZMapp maker to accelerate development of the Ebola drug (BMJ 2014;349:g5488)

thebmj.com News in brief: WHO calls for screening of travellers in Ebola areas (BMJ 2014;349:g5247, doi:10.1136/bmj.g5247)

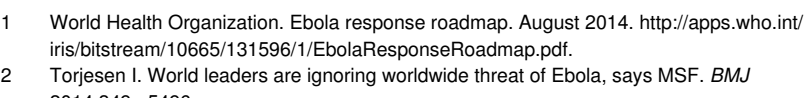

World Health Organization. Ebola response roadmap. August 2014. http://apps.who.int/ iris/bitstream/10665/131596/1/EbolaResponseRoadmap.pdf.

2 Torjesen I. World leaders are ignoring worldwide threat of Ebola, says MSF. BMJ 2014;349:g5496.

Cite this as: BMJ 2014;349:95485

๑ BMJ Publishing Group Ltd 2014 


\section{Figure}

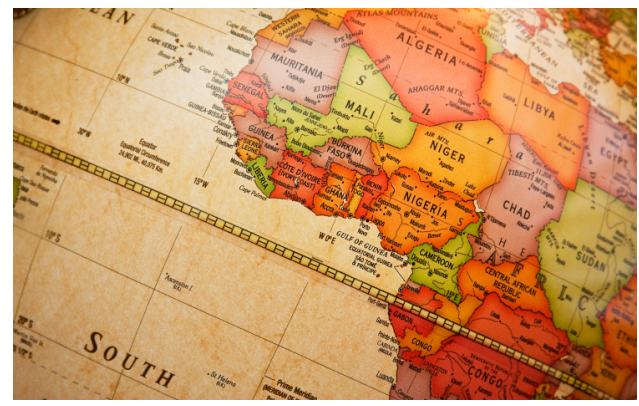

